\title{
$4^{\text {th }}$ International Conference on \\ BUSINESS, MANAGEMENT \& ECONOMICS
}

\section{Investment Guide in Qatar}

\author{
Mohammad Farhad Bakhtiarian \\ Islamic Azad University
}

\begin{abstract}
One of the manner to earning profit and having a high income, is investing in an acceptable market. The thinker brain knows, investing in the business world today, maybe, have a manifold profit or lead to failure. So, before entering in the investment market, we must have a comprehensive and sufficient awareness, know markets, acquainted with the main industrial activities, know the rules and regulation and consider the conditions of society. Qatar, as a one of the richest countries in the world, can be a good destination for investment. The inflation rate, taxes, easiness of the importing, company registration, ease of exporting process, profitable and appropriate markets, simple and applicable rules, all of this has made Qatar, one of the best and gainful investment countries. Above all, Qatar 2022 world cup event, has led of investment in this country efficiently and profitable method. In this paper, first, we have introduced the Qatar and its location, also looked at the countries international markets during the world cup and we have described the impact of the world cup on business, and then the laws and regulations of the Qatar in the field of investment, company registration, ownership by foreigners, obtaining residency by investors, export and import process in second part its examined, and in third part, major investment markets, principal industrial activities in Qatar, markets affected by the world cup and the main needs of this country in various fields during the world cup, have been investigated.
\end{abstract}

Keywords: investment, Qatar, markets, world cup 


\section{Introduction}

Qatar is a country in southwest Asia in the Middle East region east of the Arabian Peninsula and in the southern part of the Persian Gulf. Its capital is Doha. Qatar has a land border with Saudi Arabia and a water border with Iran, Kuwait, Iraq, Saudi Arabia, Bahrain and the United Arab Emirates. Qatar has vast oil reserves. Forbes magazine ${ }^{1}$ named Qatar the richest country in the world and the best country to trade. Qatar has the highest human development index among the countries of the Arab world. It has the highest per capita income in the world. Qatar has a completely gas-dependent economy and it's the largest exporter of natural gas in the world. Qatar's net income from oil and gas exports in 2014 was estimated at $\$ 38$ billion.. The per capita income of this country with about 130 thousand US dollars per year is the highest per capita income in the world. Qatar is a member of the Organization of Petroleum Exporting Countries and the third largest holder of gas reserves after Iran and Russia. Qatar is an import-dependent country and imports about half of its food. The tax rate in this country for personal income tax is zero percent and corporate tax is 10 percent. Also, the inflation rate in Qatar has not only not grown in recent years, but has also been negative. Also in export and import activities, the tax rate is up to 5\%.

\section{International markets of the country during the World Cup}

The FIFA World Cup can be considered one of the greatest opportunities for economic development of countries. The host country needs foreign capital to build and equip everything it needs during this cup, such as stadiums, transportation facilities, hotels, restaurants, etc. The economic benefits of hosting the World Cup can be seen in the 2018 World Cup in Russia. The Russian government has stated that it has so far spent about \$ 7 billion to provide the highest possible quality of hosting and games. These costs have been mainly for the infrastructure and hardware facilities of the Cup. The FIFA website has announced that 5 sports stadiums in 11 cities with a capacity of 550,000 people in Russia will host the games. 27 new hotels, 13 hospitals and 12 power stations have been built to better host the competition, and 13,000 people have been hired to renovate or build 10 stadiums. The World Cup in Russia has created 200,000 jobs. Producers and sellers also made huge profits as commodity prices rose due to increased demand. Russian handicrafts and small producers even have a share of this large market, and their situation has changed in the onemonth period of the Games. A significant portion of this expenditure was spent on infrastructure, and the Russians were able to use it after the end of the competition. During the tournament, \$ 2.3 billion in tourists entered Russia, and the economic growth of the Tsarist lands increased by one to two percent. Also, the use of the $40 \%$ credit card shopping method in this country had increased more than before. These were the direct income and influence of tourists for Russia at the time of the World Cup. FIFA rewarded Russia \$ 791 million for

\footnotetext{
${ }^{1}$ https://www.forbes.com/places/qatar/?sh=570a7e454672
} 
hosting the tournament. Rewards far greater than in previous eras that remind us of the expansion of the football business.

\section{Rules and regulations regarding investment}

Prior to this, Law No. 13 on Non-Qatari Investment, adopted in 2000, governed the investment process in Qatar. On January 7, 2019, Amir Sheikh Tamim bin Hamad Al Thani repealed Law 2000, passing Law No. 1 on non-Qatari investment. The move could stem from Saudi sanctions against Qatar that have been in place since 2017 (In June 2017, Saudi Arabia, the UAE, Bahrain and Egypt severed all ties with Qatar and imposed sanctions on the country. Qatar's economy has so far been able to cope well with the consequences of the embargo and blockade, and the Qatar Investment Fund has injected billions of dollars into various sectors affected by the suspension of Arab investment) Or knowing the rich economic opportunity of the 2022 World Cup. In any case, this action of the Emir of Qatar will lead to great progress and prosperity for Qatar. The law was passed to encourage foreign investors to invest in Qatar, and the provisions of Law No.13 of 2000 have been amended to a sufficient extent. The main change in this law compared to Law No. 13 of 2000 is that this law allows $100 \%$ ownership to foreigners. Article 2 of this law explicitly states: Without prejudice to legislations regulating Non-Qataris' practices of commercial businesses and professions, and the provisions of Article (4) hereof, a Non-Qatari Investor may invest in all economic sectors even with a capital up to $100 \%$ in accordance with the Executive Regulations of this Law. Article 3 explains the process and how to obtain the necessary licenses, that the necessary documents to increase the shares are submitted to the relevant departments of the Ministry of Economy and Industry, and the relevant unit will make a decision within 15 days. The silence of the relevant department is an implicit rejection of the request. It should be noted that the investor can file a complaint to the Minister of Economy and Industry within 15 days from the date of the announcement of the rejection, and the relevant minister will appeal within 30 days. Article 4 of this law states three of the prohibitions of this $100 \%$ privilege, which are: Banks and insurance companies unless excluded by decision of the Cabinet, and 2 . Commercial agencies, and 3. Of course, any other field that is banned by the decision of the Council of Ministers. According to the law, non-Qatari investors can bring into the country everything they need to launch the operation or extend the project. (Article 9) Qatar has provided acceptable incentives to investors regarding the imported machinery and equipment needed to launch the project. Article 11 of Law No. 1 states; Non-Qatari investment projects shall be exempted from custom taxes in respect to imported machinery and equipment needed for setting up the projects. Non-Qatari investment industrial projects shall be exempted from customs on imported raw and half-manufactured materials which are needed for production and which are not available in domestic markets. With this interpretation, an acceptable exemption for investing in Qatar is envisaged. Article 10 also acknowledges; Non-Qatari Investment projects may be exempted from income tax in accordance with controls, procedures and periods provided in the aforementioned Law of Income Tax. These exemptions are not the only incentives for investment in Qatar, because according to Article 12, based on the proposal of the Minister of the Council of Ministers, in addition to the 
envisaged cases, they can also grant more incentives to investment projects. ${ }^{2}$ Finally, Article 25 of this law states the cases of non-compliance with the law; The provisions of this Law shall not apply to the following:

1- Companies and individuals who are assigned to extract, utilize or manage natural resources under a concession or special contract, to the extent that the provisions of such do not contradict the provisions hereof;

2- Companies which the government or any other public authority or institution sets up or participates in; and companies in which the government participates in partnership with NonQatari Investors in a percentage of no less than $51 \%$, or in a lesser percentage subject to the approval of the Council of Ministers, in accordance with the abovementioned Commercial Companies Law; and

3- Companies or individuals licensed by Qatar Petroleum to carry out any petroleum activities or which aim to invest in the oil and gas and petrochemical sector.

\section{Registration of company}

The Qatari government has always wanted the process of foreign investment in the country to be easy. Law No. 1 of 2019 was approved for the same purpose. The rules and process of registering a company in Qatar is also easy. The first step in registering a company in Qatar is to choose a name. Investors wishing to register a company in Qatar must first submit their proposed name to the Ministry of Industry and Trade. The submitted trademarks should not be duplicates and therefore a section called $\mathrm{MBT}^{3}$ has been set up so that investors can see the list of registered companies and be sure that their chosen trademark is not duplicate. The next step is to open a bank account called the company and deposit the initial capital. In the third step, investors must prepare the company's articles of association according to the proposed format of MBT and submit it to the Ministry of Industry and Trade. It is noteworthy that this process will take less than 48 working hours. The final step in registering a company in Qatar is obtaining a business license. The Qatari Ministry of Trade and Industry will be the custodian and issuer of this license, which will take less than a day to obtain. Government fees for obtaining a license will vary from 200 to 10,000 Qatari riyals. The company registration process in Qatar will take a total of 15 to 30 working days( According to Law No. 5 of 2002 related to the Company Registration Law). The types of companies in Qatar are stated in Article 4 of Law No. 5 as follows; The company which is established in Qatar should take any of the following forms:

1- Joint Company

2- Limited Partnership Company

${ }^{2}$ Article (12) Based on the Minister's proposal, the Council of Ministers may grant the investment projects further incentives and privileges in addition to those provided in this Law./ Law no. (1) of 2019 On Regulating Non-Qatari Capital Investment in the Economic Activity

${ }^{3}$ Ministry Of Business \& Trade 


\section{$4^{\text {th }}$ International Conference on BUSINESS, MANAGEMENT \& ECONOMICS}

3- Particular Partnership Company

4- Shareholding Company

5- Equities Partnership Company

6- Limited Liability Company

Article 17 of the law states that foreign companies operating in Qatar are also governed by the same law.

\section{residence by international investors}

Qatar does not grant citizenship to foreign investors, and previously investors had to be supported by a Qatar to stay in Qatar, but according to the new regulations, investors can apply for a five-year residency, which can be extended for another five years.

\section{Major investment markets in Qatar}

Foreign investors can invest in different ways and in different markets in Qatar. The first major market to be invested in Qatar is the Qatar Stock Exchange. The Qatar Stock Exchange is the 33rd largest global stock market. Investors can invest in the Qatar Stock Exchange through brokerage. The second way to invest in Qatar is to register a company to start a project and trade in this country. The new foreign investment law in Qatar has made Qatar one of the most important investment destinations in the world, as explained in the previous sections. Investing through opening a bank account and investing through buying real estate are other major investment markets in Qatar.

\section{Markets affected by the World Cup}

The 2022 World Cup in this country has made Qatar one of the investment targets in the world. One of the reasons for this is the need of this country in some major markets. Qatar is building and equipping stadiums, hotels, restaurants and public transport, which requires foreign investment and the development of investment laws.

\section{Major industrial activities in Qatar}

Undoubtedly, before this, Qatar's major industrial activities were summarized in the country's oil and gas markets. But now, with the 2022 World Cup event, the country's construction markets have grown rapidly. So that with the construction of several stadiums, hotels, restaurants and .... Qatar Civil Market will also be a good destination for investment. 


\section{$4^{\text {th }}$ International Conference on \\ BUSINESS, MANAGEMENT \& ECONOMICS}

15 - 17 DECEMBER 2020

BERLIN, GERMANY

\section{Conclusion}

The 2017 sanctions against Qatar, as well as the 2022 World Cup, have made Qatar one of the world's investment targets. The tax rate in this country has been zero percent for individuals and ten percent for companies and industrial activities in recent years. Also, with the approval of the new Foreign Investment Law No. 1, approved in 2019, foreign investors can own up to $100 \%$ of their projects, which is one of the biggest advantages offered to investors. Construction markets such as the construction, equipment and operation of stadiums, hotels, restaurants, as well as public transportation for the 2022 World Cup are among the main investable markets in Qatar. Registering a company in Qatar can be done easily and maybe in a period of 15 to 30 days, and this will help the process of attracting capital in Qatar. According to the data presented in this paper, Qatar is one of the best and of course the least risky countries for investment.

\section{References}

\section{Books}

1. Graham, Benjamin, (2006) The intelligent investor, Harper Business; Revised ed. edition (February 21, 2006)

2. Vora, Neha , (2018) Teach for Arabia: American Universities, Liberalism, and Transnational Qatar, Stanford University Press; 1st edition (December 11, 2018)

3. Gillespie , Frances , (2016) Discovering Qatar , Medina Publishing; 2nd edition (July 15, 2016)

4. Coates Ulrichsen, Kristian , (2014) Qatar and the Arab Spring , Oxford University Press; 1 st edition (December 15, 2014)

5. W. Clarkson , Miller , B. Cross , (2017) Business Law: Text and Cases , Cengage Learning; 14th edition (January 1, 2017)

\section{Journal}

1. Almujamed, Hesham , (2018) Predictable returns in an emerging stock market: Evidence from Qatar, Accounting, corporate governance and business ethics, research article, First Published: 11 July 2018

\section{Online sources}

1. Forbes magazine, https://www.forbes.com/places/qatar/?sh=570a7e454672 